Article

\title{
Determinants of Consumer Intentions to Purchase Energy-Saving Household Products in Pakistan
}

\author{
Saqib Ali ${ }^{1}$, Habib Ullah ${ }^{1}$, Minhas Akbar ${ }^{1, *} \mathbb{1}$, Waheed Akhtar ${ }^{2}$ and Hasan Zahid ${ }^{3}$ \\ 1 Department of Management Sciences, COMSATS University Islamabad (Sahiwal Campus), \\ Sahiwal 5700, Pakistan; saqibali@cuisahiwal.edu.pk (S.A.); habib.ullah@outlook.com (H.U.) \\ 2 Faculty of Management Sciences, International Islamic University, Islamabad 44000, Pakistan; \\ waheed.akhtar@cuisahiwal.edu.pk \\ 3 Ghazali Shafia Graduate School of Government, Univesiti Utara Malaysia, Kedah 06010, Malaysia; \\ hasan_zahid1@gsgsg.uum.edu.my \\ * Correspondence: minhasakbar@cuisahiwal.edu.pk
}

Received: 25 January 2019; Accepted: 27 February 2019; Published: 9 March 2019

\begin{abstract}
The looming threat of climate change has become an undeniable harsh reality. Inefficient energy consumption is one of the major causes of this threat. Protecting the aquatic and terrestrial environment by reducing carbon footprints is a shared responsibility. In this pursuit, the contribution of household sector is extremely valuable and use of energy-saving products can be helpful to epitomize the goal of achieving sustainability. This study aims to investigate the determinants of consumers' intention to purchase energy-saving household products by integrating the Theory of Planned Behavior (TPB) and Technology Readiness Index (TRI) 2.0's four indicators (optimism, innovativeness, discomfort and insecurity). This study applied a hypo deductive research approach. Using cross sectional data, a total 396 valid questionnaires were collected to validate the proposed hypothesis by using Partial Least Square (PLS) path modeling approach (a variance based SEM technique). Results showed that contributors of technology readiness positively influence residents' attitude towards their buying intention, while inhibitors of technology readiness negatively affect this relationship. Further, attitude and perceived behavioral control were found to be significant determinants of intention to purchase energy-saving household products. Based on the above research findings, implications for marketers and policy makers are discussed, moreover future research directions are suggested.
\end{abstract}

Keywords: Energy-saving household products; consumer purchase intentions; Theory of planned behavior; Technology readiness index; Pakistan

\section{Introduction}

The concept of sustainability is a major topic and has been high on research and policy agendas for several decades. It is becoming increasingly important to reducing the global environmental footprint because it is a major factor that affects the sustainable development of the global economy since the start of the 21st century [1]. Further empirical evidence also indicates that environmental and sustainability issues in recent years have become a major concern for global organizations such as the Organization for Economic Cooperation and Development and the United Nations [2]. The environment has changed a great deal since the beginning of industrialization. The human race has deteriorated the Earth's climate by exploiting natural resources, polluting water, soil, and air. This green planet is now at the risk of survival. Rising energy consumption around the globe is adding to this grave threat $[3,4]$. In today's world there is growing awareness that irrational energy consumption leads towards environmental pollution and unsustainable development $[5,6]$. While, combating climate 
change and attaining a sustainable environment has become a shared responsibility [7]. The current world population is 7.6 billion, which is projected to reach 8.6 billion in 2030, 9.8 billion in 2050, and 11.2 billion in 2100 [8]. This population surge and materialistic lifestyles will escalate the demand for electricity consumption. Apart from industry, the residential sector has shown strong growth in energy demand [7]. The world energy outlook 2017 has indicated that the global residential energy demand is expected to rise $32 \%$ from now until 2040 due to population growth [9]. The upsurge in energy consumption has led towards many environmental crises such as climate change and the destruction of natural resources that used to produce energy [10]. In relation to these issues, Rafique \& Rehman, 2017 [5] argued that rampant usage of fossil fuels for energy generation drives the big wheel of environmental degradation which affects human societies, woodlands and animal habits. Hence, it is becoming increasingly important to promote energy efficiency behavior for the sustainable development of a country in the case of resource constraints.

The household sector can make a significant contribution to environmental conservation and sustainability by using energy-saving products. Shrinking energy demand and enhancing efficiency are broadly viewed as the most optimistic, swift, economical and secure approaches to alleviating environmental disruptions and climate change [11,12]. Policymakers around the world have been emphasizing on individuals' obligation of their actions that can affect the environment. These incorporate recycling, using green label items, and minimizing electricity consumption [13]. Products that diffuse energy quickly is viewed as a key choice for accomplishing efficiency and lessening carbon emissions [7,14,15].

A recent study in China revealed that household products are responsible for $70 \%$ of family carbon dioxide emissions, while air conditioners(ACs), TVs, and refrigerators account for $50 \%$ of these emissions [16]. In 2006, a European Commission report for energy efficiency plan estimated that efficient energy use can save upto $27 \%$ of current household energy consumption [17]. Benefits of this approach can be three fold; first, the use of energy-saving household products can reduce global energy consumption. Secondly, the residential sector can significantly contribute to mitigating carbon emissions $[18,19]$. Thirdly, developed countries are decreasing carbon emissions and implementing environmental protocols, however they are also relocating their polluting industries to less developed countries [20,21]. But no country can shift their household sector to other countries, so implementing energy policies in this sector can be very effective [22].

The world is witnessing better living standards, improved household incomes and a rising trend of urbanization; all these factors are eventually adding billions of home appliances around the globe [7,23]. Every year, 5 million TVs and 4 million refrigerators are being replaced in China alone [24]. Ownership rates of major home appliances in first world countries are more than $85 \%$ per home $[23,25]$. Similar trends are expected to occur in developing countries where this ownership rate is projected to rapidly increase and reach 70\% per home by 2030 [23]. A recent study by Parikh and Parikh, 2016 [23] on energy saving potential of four major home appliances (AC, TV, Fan \& Refrigerator), estimated possible savings of 52 billion Kwh to 145 billion Kwh by 2030 which accumulates to up to $27 \%$ in energy savings. Further estimates show that by using energy saving versions of these appliances, a 30\% reduction in carbon emissions can be achieved by 2030 [23]. These numbers reflect the potential economic and environmental effects of using energy saving home appliances.

Home to 208 Million people, Pakistan is the world's 6th most populous country [26]. Hit by a severe energy crisis, Pakistan has faced declining economic growth and political instability. Energy deficiency has cost Pakistan up to a $4 \%$ loss in GDP over the past few years [27]. Supply and demand curve shows a huge gap and this shortfall is resulting in 8 to $10 \mathrm{~h}$ of load shedding in urban areas and 12 to $14 \mathrm{~h}$ in rural areas [28]. Pakistan's deficiency of energy resources has increased its imports bill. Pakistan spends around $60 \%$ of its total foreign exchange funds on the import of fossil fuels [29]. According to a Water and Electricity Ministry press release, total installed capacity is 28,000 MW, while $18,742 \mathrm{MW}$ is being produced. The demand expansion rate is $10 \%$ per anum while capacity is growing at $7 \%$. Projections show that demand will reach 45,000 MW by $2030[5,30]$. 
The household sector dominates total electricity consumption in Pakistan by utilizing $46 \%$ of total electricity usage. Future demand projections show that households will keep on leading this usage and will grow at 9\%, while industrial demand will increase by 3.8\%. Increasing population, improving life standards, rapid urbanization, growing middle class all are growth multipliers for household sector energy demand. During the last 15 years, $85 \%$ of new household consumers have been added and by 2050, a threefold increase is expected [5]. Pakistan is in dire need of not only the addition of new energy sources but also efficient energy management. The country is witnessing a growing middle class. Sales of air conditioners, refrigerators, TVs, washing machines and other electronic products are rapidly increasing [31]. Products that are energy efficient can help in reducing the energy demand; this will eventually ease the pressure on the national electricity grid. On the other hand, their use will also be helpful for reducing carbon emissions and increasing environmental sustainability [29,32].

Understanding household behavior towards energy-saving products is of the utmost importance for policy makers; manufacturers and marketers [7]. Household energy saving behavior has been well investigated in developed countries such as Germany [15], the UK [33], Australia [34], the Netherlands [35], Switzerland [36], the US [37] and Sweden [13]. However, there is a lack of related research on household energy saving behavior in developing countries, where the demand for electricity is expected to rise by $30 \%$ until 2040 [9].

Attempts to understand how household energy saving behavior should be encouraged; the majority of the pro environmental, energy saving behavior research has focused on the role of values, attitudes, beliefs, and personal norms in shaping household electricity saving behavior. However, among these studies, a less-studied research area is how an individual's readiness to use new technology oriented energy efficient home appliances by using four personality traits: optimism, innovativeness, discomfort, and insecurity. Hence, to narrow down contextual and literature gap, this study incorporates the four personality traits of Technology Readiness (TR2.0) in the Theory of Planned Behavior (TPB) to examine the intention of consumers towards buying energy saving household products.

\section{Literature Review}

\subsection{Theoretical Background}

TPB which provides an essential foundation to study individual behavior was developed by Ajzen, 1991 [38]. TPB fetches its roots from the Theory of Reasoned Action (TRA) and is one of the most widely used theories to study human behavioral aspects. The theory implies that a person's behavioral intentions are influenced by three factors: attitudes, subjective norms and Perceived Behavioral Control (PBC). While, attitude is a measure of a person's assessment as being favorable or unfavorable about the outcomes of performing a particular behavior, subjective norm is the influential degree of peers' opinions and perceptions while performing a specific behavior. PBC is an individuals' degree of control over the execution of certain behavior [14]. The peculiar behavior in question lies inside the domain of environmentally friendly behavior [39]. A review of pro-environment and green purchase behavioral studies reveals that TPB has been used to support several research efforts e.g., Reyes et al., 2018 [40], Gadenne et al., 2011 [34] and Millock \& Nauges, 2010 [41]. Considering the particular domain of household energy saving behavior, TPB has been put into action by several researchers (Table 1).

TPB provides a valuable framework to study residents' intentions of buying energy-saving products. Synthesis of new variables that can affect these intentions will enhance TPB's explanatory power [7].

Literature on green purchase intentions has been studied through the lens of cognitive antecedents of behavior. Although behavioral researchers have improved the explanatory power of TPB by adding personality constructs [42], there is a scarcity of research on the relationship between personality traits and eco-friendly behavior [43,44]. Dezdar, 2017 [45] also identified that not many behavioral studies have employed personality traits as a factor that influences eco-friendly behavior. The past few years have witnessed enormous technological growth and an influx of high tech products, which has 
facilitated new behavioral patterns [46]. Researchers point to differences in peoples' disposition towards using technology $[47,48]$. This creates an acute research gap in how technology related personality traits impact consumer intentions of buying energy-saving household products. So far no effort has been made to incorporate technology based personality trait concepts such as the Technology Readiness Index (TRI) and cognitive antecedents (TPB) to study energy saving behaviors.

Table 1. Use of TPB in Residential Energy Saving Behavioral Research.

\begin{tabular}{|c|c|c|c|c|}
\hline Year & Authors & Country & Context & Constructs \\
\hline 2012 & Ha \& Janda & South Korea & Household energy saving & $\begin{array}{l}\text { Attitude, Subjective Norm, Belief } \\
\text { about energy efficient product, } \\
\text { Knowledge about energy efficient } \\
\text { product, Environmental awareness, } \\
\text { confidence of consequence, Eagerness } \\
\text { of environmental engagement }\end{array}$ \\
\hline 2014 & Wang et al., & China & Household energy saving & $\begin{array}{l}\text { Attitude, Subjective Norm, Perceived } \\
\text { Behavioral Control, Information } \\
\text { Publicity, Living Habits, Energy } \\
\text { Knowledge, Demographic Variable }\end{array}$ \\
\hline 2017 & Tan et al., & Malaysia & Household energy saving & $\begin{array}{l}\text { Attitude, Subjective Norm, Perceived } \\
\text { Behavioral Control, Moral Norms, } \\
\text { Environmental Concern, } \\
\text { Environmental Knowledge }\end{array}$ \\
\hline 2017 & E. Park \& S.J. Kwon & South Korea & Household energy saving & $\begin{array}{c}\text { Intention to use, Perceived Benefits, } \\
\text { Perceived Value, Perceived risk, } \\
\text { Social Responsibility, Environmental } \\
\text { Knowledge, Trust, Perceived Cost, } \\
\text { Actual usage }\end{array}$ \\
\hline 2017 & Wang et al., & China & Household energy saving & $\begin{array}{l}\text { Attitude, Subjective Norm, Perceived } \\
\text { Behavioral Control, Residual effect }\end{array}$ \\
\hline
\end{tabular}

This theoretical framework can not only help to describe consumer intentions towards the purchase of energy saving products but will also explain how technology embedded personality traits can shape and impact these intentions. TRI by Ananthanarayanan Parasuraman, 2000 [49] is a tool used to measure technology related personality traits. Based on insights from extensive experience and significant changes in the technology landscape, the authors revised this index into TRI 2.0 [46]. This study proposes an integrative theoretical research model (see Figure 1) based on TPB and TRI to provide us new insights into the undertaken topic.

Technology Readiness

Theory of Planned Behavior

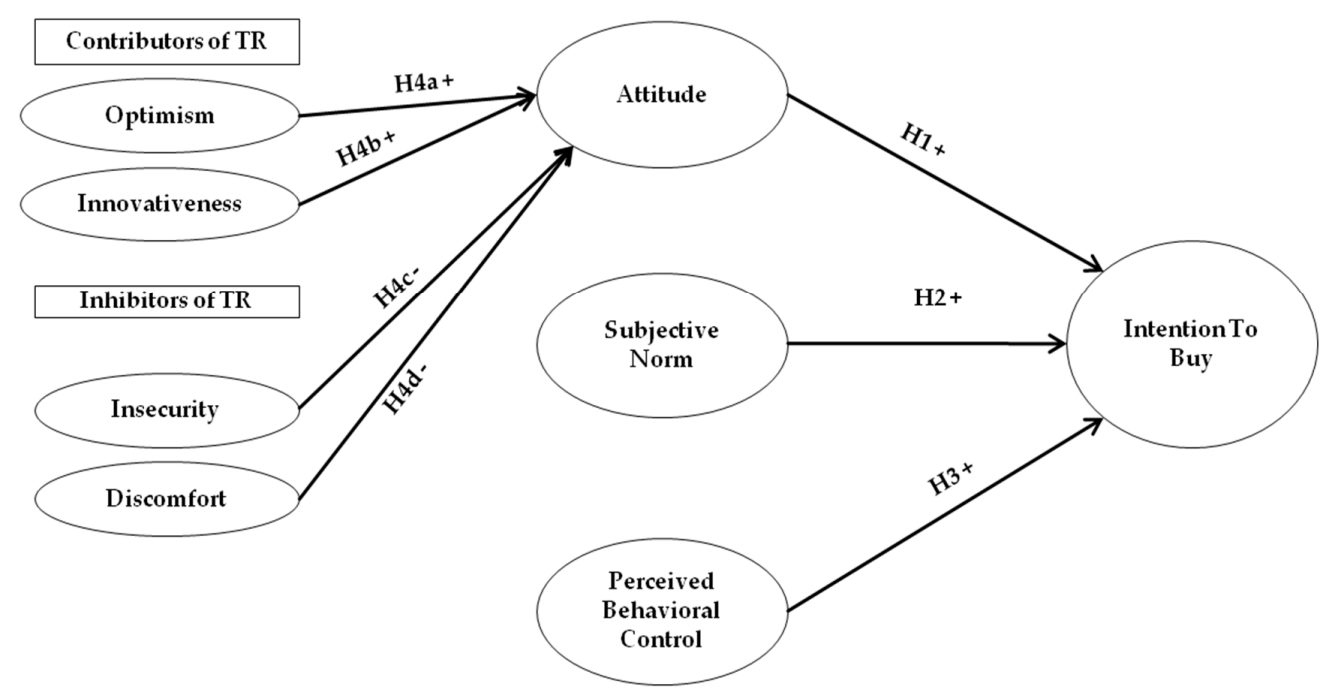

Figure 1. Theoretical research model. Source Authors' construction. 


\subsection{Empirical Evidences and Hypothesis Development}

\subsubsection{Attitude}

"Attitude is a mental state of readiness learned and organized through experience, exerting a specific influence on a person's response to the people, objects, and situations to which it is related" [50]. The above definition is an echoing note to the TPB [38], which explain how favorable attitudes towards performing a specific behavior are an indication that the person will undertake that action. Attitude was defined specifically to describe the energy saving behavior of household consumers as, "the degree of people awareness of performing electricity-saving behavior, which largely depends on the evaluation of preference to electricity savings and the information the individual holds towards such a behavior" [14]. Attitude is formed by information about and experiences of a specific behavior [38]. A customer may think favorably about a less expensive refrigerator because of affordability, i.e., he has a positive attitude towards buying this refrigerator. However, after getting more information about competitive products, he may get ready to buy a more expensive refrigerator. This information can include electricity efficiency, environmental effects, price and durability. The final intention of buying a particular appliance depends on beliefs about positive consequences of such transaction and individual's favorable attitude towards those beliefs [7].

The consumer's attitudes towards environmental issues area strong indicator of their energy saving behavior [13]. Similar results were confirmed by Zografakis et al., 2010 [51], who concluded that residents with positive attitudes towards the environment and knowledge of energy savings are more likely to purchase energy-saving products. Many researchers have confirmed this viewpoint that attitude is one of the most important and relevant predictors of purchasing intentions of energy-saving products $[7,16,34,35,52,53]$. By incorporating the prior research and available literature, we can form our first hypothesis:

Hypothesis 1 (H1). Residents' attitudes toward energy-saving products have a direct positive relation with their intention to buy these products.

\subsubsection{Subjective Norms}

Individual perceptions are named as subjective norms or examples of an "opinion about what important others believe the individual should do" [54]. Subjective norms in simple words are perceptions absorbed from our surroundings that force us to act on or refrain from an action or behavior [35]. People's impressions of their outside environment influence their conduct significantly [14]. Family and peer influences play an important role in forming these subjective norms. Their opinions and perceptions can build pressure to perform energy saving efforts [55].

Subjective norms are not as wide a domain as social norms but they are normative beliefs and can be explained as "located within, but not identical to the broader construct of social norms while social norm refers to a rather broader range of permissible, but not necessarily required behavior" [38]. Normative belief leads to a particular social act, the execution of which is normal or wanted under the given circumstances [56]. Subjective norms positively affect intentions towards environmentally friendly behavior [34]. The main force behind such a behavioral intention is the belief that environment should be protected, there is a need to deal with climate change effects, and that this is a shared responsibility in which everyone should participate [57]. Individuals feel an obligation when they comprehend what is happening and the outcomes of their activities. A clean-living, righteous, moral and upright obligation leads towards such forms of behavioral intention [36].

Several studies on green buying behavior have found subjective norms to be a significant determinant of consumers' buying intentions [58-61]. Ha \& Janda, (2012) [53] conducted a survey in South Korea using structured questionnaires to predict consumer intentions of buying energy-saving products. They found that subjective norms have a strong influence on energy-saving behavior. This point of view was further verified by Wang et al., 2014 [14]. Likewise assuming that subjective 
norms will positively influence buying intentions for energy saving products, we develop our second hypothesis:

Hypothesis 2 (H2). Subjective norms are directly and positively related with residents' intentions to buy energy-saving products.

\subsubsection{Perceived Behavioral Control}

"Perceived Behavioral Control (PBC) is the degree of difficulty experienced by an individual in maintaining rationality when perceiving a certain event" [55]. The extent to which a person feels ready to participate in a specific behavior is referred to as PBC [38]. Tan et al., (2017) [7] defined PBC as an individual's perceived ease or difficulty in performing a specific behavior. $\mathrm{PBC}$ has been an important instrument to study consumer purchase intentions. A number of scholars have used this variable to predict green buying behavior, such as Klöckner [62].

PBC is a twofold concept, involving both the amount of control an individual has over his or her behavior, and the amount of certainty an individual feels in order to perform or not perform that specific behavior [38]. PBC strongly depends on one's beliefs towards the impacts of internal and situational factors which can accelerate performance of the specific behavior. The more control an individual has over the energy-saving appliance being considered; the more probable it is for that individual to utilize it [63]. Comfort, time, and financial costs are the primary limitations influencing PBC. Energy saving behavior is directly dependent on the degree of residents' PBC [64]. An investigation on energy saving behavior of UK citizens revealed that cost savings and comfort of use significantly improved residents' behavior towards these products [65].

In an echoing note, Wang et al., (2014) [14] reiterated that PBC is strongly and positively correlated to the energy saving behavioral intentions of citizens. This point of view has been further verified by Alam et al., (2014) [64] who studied household energy saving intentions in Malaysia. A recent study has also strengthened this relationship by asserting that PBC significantly influences consumers' purchase intentions of energy-saving home products [7]. Similarly, we expect that PBC is an important determinant of household consumers' intentions to buy energy-saving products thus, we develop our third hypothesis:

Hypothesis 3 (H3). Perceived behavioral control is positively and significantly related to residents' intentions of buying energy-saving products.

\subsubsection{Technology Oriented Personality Traits-Technology Readiness (TR)}

"The technology-readiness refers to people's propensity to embrace and use new technologies for accomplishing goals in home life and at work" [49]. Technology enrichment has achieved market capitalization for smart home products manufacturers like Samsung, GE, Philips, Bosch, Whirlpool, Haier and others [66,67]. This denotes the ascending importance of technology in daily household life. Tech-based products are gaining high market share at an accelerating pace around the globe [67]. Indeed this trend is more evident in developing nations than in developed ones [68]. Tech-innovation in household energy-saving products is resulting in fewer costs, greater market share and improving end user satisfaction $[69,70]$.

Energy saving by households has been made possible by technological advancements [71]. Participants in the energy-saving building equipment value chain are creating new and innovative products and services [72]. Energy-saving technologies including DC inverter technology (DC inverter air conditioners, refrigerators, and fans), LED Technology (lights, flat screen TVs), high tech washing machines and dryers and solar technology based products are a few examples of the above phenomena. Proliferation of such products poses serious challenges both for producers and for end users [46].

Technological growth has paved its way to ease energy saving challenges for consumers. In addition, the role of technology based products is increasing in everyday life. Individuals have to 
deal with products and services that are sophisticatedly designed and offer latest technology which sometimes creates difficulty of operation and usage for consumers [49]. In a study on "The influence of technology anxiety on consumers" by Meuter et al., 2003 [73], it was found that many consumers feel anxiety when using new technology, while Tsikriktsis, 2004 [74] named these experiences as being "Technophobia". In a similar tone, Bruner \& Kumar, 2007 [75] further added that many consumers resist change from old to new technology and they remain skeptical of the said benefits of making this shift. Many people are not comfortable with new technological products and they try to avoid them. People's behavior differs in adopting new technology and not everyone is ready to accept these advanced products. Indeed our personality related traits play an important role in our buying intentions for new tech based products. This creates an acute interest to check the technology readiness of end users [49,76]. TRI 2.0 is a scale developed by A. Parasuraman \& Colby, (2015) [46] in order to predict people's readiness to adopt and use new technology by applying technology embedded personality traits. TRI is a widely used construct to investigate consumers' technology related behavioral intentions. TRI is composed of four personality based dimensions. The Technology Readiness (TR) model provided by A. Parasuraman \& Colby, (2015) [46] proposes innovativeness and optimism as contributors towards new technology adoption, while discomfort and insecurity are inhibitors. These four variables are explained below along with their respective hypotheses.

\section{Optimism}

The personality trait of optimism is defined as "How positively a person perceives technology and believes that it offers people more control, flexibility, and efficiency in their lives" [49]. Optimism is an individual's positive tendency towards using technology and feeling that it brings good effects in life. This is a general construct for determining peoples' specific feelings that technological development is a positive development [76,77]. Such people utilize more dynamic adapting techniques than others in daily life, these strategies are more viable in accomplishing constructive results [78]. Optimists are less inclined towards negativities and embrace technology easily as they perceive it more helpful and simple to use. They are less chafed about the pessimistic results of innovation [43]. In simple words, optimists believe that technology can give them more control over their lives, it can increase work efficiency and that it gives them freedom in many aspects [74]. Walczuch et al; (2007) [43] stated that optimism has a significant effect on behavioral attitudes that lead towards technology adoption. In a similar vein Tsikriktsis, 2004 [74] also confirmed the association between optimism and attitudes. However, the relationship between optimism and attitudes and its effect on intentions to adopt energy-saving household products are predominately ignored by the researchers in both developed countries and developing countries (i.e. Pakistan). Hence, we form our next hypothesis to bridge this gap in the literature:

Hypothesis 4a (H4a). Optimism has a positive relationship with residents' attitude towards their intentions of purchasing energy-saving household products.

\section{Innovativeness}

Innovativeness is the "Inclination towards using high tech products and becoming a technology pioneer and a thought leader" [49]. This technology related personality trait is the degree to which an individual trusts that he or she is at the front line of experimenting with new technology products and others value his or her opinion regarding such advanced technological issues [74]. Walczuch et al., (2007) [43] assert that innovativeness is a human trait, a generally stable descriptor of an individual and does not depend upon circumstances (independent of intrinsic and extrinsic factors). People scoring high in innovativeness are early adopters, are motivated to try and accept new technologies, and have a clear set of beliefs regarding new technology. Such individuals have positive impressions of the usefulness of technology and they are not reluctant to adopt it even when its benefits and values are uncertain and dubious [78]. Scholars stress that a person's innovativeness plays an important role 
in the investigation of consumers' adoption of new technology [76,79]. However, behavioral studies show contradicting results of this relationship [44,80], meaning there is a need to test this relationship. Based on the above discussion, this study proposes the following hypotheses:

Hypothesis $\mathbf{4 b} \mathbf{b} \mathbf{H} \mathbf{4 b})$. Innovativeness has a positive relationship with residents' attitude towards their intentions of purchasing energy-saving household products.

Insecurity

Insecurity can be defined as "Distrust of technology, stemming from skepticism about its ability to work properly and concerns about its potential harmful consequences" [46]. Insecurity is a lack of trust towards technology and suspicion that it will not work properly. Those who experience higher degrees of insecurity perceive the possibility of some risks involved with using new technology [81]. Insecurity results in people avoiding the use of new technology products because of their intrinsic fear of technology [43]. Research has found that $25 \%$ of Americans were "very insecure" towards digital alarm clock usage in 1995 [82]. The associated risk brings a sense of insecurity and such individuals need assurance. Confidence in using new tech is inversely proportional to the amount of insecurity. People with higher insecurity have lesser confidence towards adopting such products [78]. While the TR Model proposed by A. Parasuraman \& Colby, 2015 [46] comprehensively supports insecurity as an inhibitor towards consumer intentions of adopting new technology, marketing literature is filled with mixed findings $[77,78,80]$. Therefore, it is important to empirically test whether insecurity negatively influences consumers' attitudes towards the adoption of new technology energy-saving home products or not. We propose our next hypothesis:

Hypothesis 4c (H4c). Insecurity has a negative relationship with residents' attitude towards their intentions of purchasing energy-saving household products.

\section{Discomfort}

This technology related personality trait is defined as "A perceived lack of control over technology and a feeling of being overwhelmed by it" [49]. People with this trait feel uncomfortable and anxious about use of technology as they think that technology is controlling them. They are doubtful about its usefulness for ordinary people [47,76]. Tsikriktsis, 2004 [74] asserts that discomfort "represents the extent to which people have a general paranoia about technology-based products and services believing that they tend to be exclusionary rather than inclusive of all kinds of people". Previous researchers have found that discomfort negatively influences perceived ease of use of technology and that there is an inverse relationship between these two variables. According to the technology acceptance model [82], perceived ease of use is a key determinant of consumers' attitudes towards technology adoption [43,77]. Hence bridging the existing gap in the literature, we construct a relationship between discomfort and attitude by assuming the following hypothesis:

Hypothesis $4 \mathbf{d}(\mathbf{H} 4 \mathbf{d})$. Discomfort has a negative relationship with residents' attitude and intentions towards purchasing energy-saving household products.

\section{Methodology}

A quantitative approach using the survey questionnaire method was used to examine household intentions to purchase energy-saving household products. The questionnaire of this study consisted of two parts. Section A contains respondent demographic information of five variables: gender, age, occupation, educational level and household monthly income (See Table 2). Section B includes constructs measurements that were adopted/adapted from prior literature. Technology readiness (sixteen items) were adapted from A. Parasuraman \& Colby, (2015) [46], attitude (five items) was adapted from Ha \& Janda, 2012 [53] and Ninh \& Lobo, 2016 [83], subjective norm (four items) was 
adapted from Chen \& Tung, 2014 [59] and Ninh \& Lobo, 2016 [83], perceived behavioral control (four items) was adapted from Alam et al., 2014 [63] and purchase intention (four items) was adapted from and Ninh \& Lobo, 2016 [83].

A 7 pointlikert scale was adopted that ranged from strongly disagree $=1$ to strongly agree $=7$. The questionnaires, pre-test and pilot-test were conducted to ensure its reliability and validity for this research. The data was collected from March 2017 to May 2017 from metropolitan cities, namely; Faisalabad and Lahore. Faisalabad and Lahore are the largest urban centers in Pakistan, and include six neighboring cities. The demand of efficient household appliances (i.e., washing machines, air conditioners, refrigerators, cooling fans and water pumps) has notably surged in the metropolitan cities. The non-probability (purposive) sampling technique was employed because it is appropriate when it is difficult to get a complete sampling frame. This type of sampling is suitable because it permits a theoretical generalization of the findings. According to Churchill \& Iacobucci, 2006 [84], the minimum sample size in regional consumer study should range between 200-500 responses. Hence, in this research, 400 valid questionnaires were sufficient to analyze the data. The respondents comprised of young consumers (18-30 years), because young adults are more concerned about environmental conditions and they have a greater ability to reflect their choices towards eco-friendly products [85]. Moreover, young adults (18-30 years) are more informed about energy-saving household products in different ways, such as social media, friends and advertisement, etc. A total 742 questionnaires were distributed, of which 460 were returned and finally after primary screening, 396 questionnaires were found to be useable for the present study (see Table 2).

Table 2. Demographic profile of respondents.

\begin{tabular}{cccc}
\hline & Characteristics & Frequency & Percentage $\%$ \\
\hline Gender & Male & 274 & 69.2 \\
& Female & 122 & 30.8 \\
\hline Age & $18-22$ & 45 & 11.4 \\
& $23-27$ & 146 & 47 \\
& $28-30$ & 165 & 41.7 \\
\hline Education & Primary level or low & 44 & 11.1 \\
& Secondary level & 72 & 18.2 \\
& Graduation level & 184 & 46.2 \\
& Post-graduation level or higher & 96 & 24.2 \\
\hline Occupation & Student & 119 & 30.1 \\
& Service professional & 148 & 37.4 \\
& Businessmen & 129 & 32.6 \\
\hline Household monthly income & Less than 50,000 Rs & 21 & 5.3 \\
& $50,001-$ less 100,000 & 63 & 15.9 \\
& $100,001-$ less 150,000 & 95 & 24 \\
& 150,001 Rs and Over & 217 & 54.8 \\
\hline Ever purchased energy-saving & Yes & 290 & 73.2 \\
household products in the past? & No & 106 & 26.8 \\
\hline
\end{tabular}

\section{Results}

\subsection{Data Analysis (PLS SEM)}

Structural Equation Modeling (SEM) has an advantage for statistical analysis in term of efficiency, accuracy and convenience over traditional multivariate statistical techniques [86-88]. SEM is a robust and influential high quality second-generation multivariate statistical analysis technique for parameter assessment and hypothesis testing which incorporates first generation statistical procedures e.g., factor analysis and regression or path analysis. The application of SEM in business research is gaining popularity [87]. SEM has two well-known techniques: covariance-based SEM (CB-SEM) and Variance-Based SEM (VB-SEM) [89]. Choosing a suitable statistical technique is vital for social science 
researchers because inappropriate selection of statistical techniques can cause inaccurate conclusion or inexact results [90]. Because data tend to have the problem of normality in social science studies [91] hence, Partial Least Square (PLS), which is also known as VB-SEM and is commonly used to address the problem of normality, is preferred over CB-SEM and was used here.

In this study, PLS-SEM is performed to analyze the theoretical model by using SmartPLS 3.0 [92]. The PLS-SEM approach presents results in two phases, the first being the measurement model and the second being the structural model [93-96]. This study tested both the measurement model (validity and reliability of measures) and the structural model (testing the hypothesized relationship) by following the suggested two-stage analytical procedures [97]. Moreover, to assess the significance of the path coefficients and the loadings, a method of bootstrap resampling of 5000 subsamples was used [98].

\subsection{Measurement Model Evaluation}

The measurement model has been established with a reflective indicator. The measurement model is assessed by examining two types of validity: convergent validity and discriminant validity. Convergent validity of the outer model or measurement model is determined by evaluating the outer loadings, Average Variance Extracted (AVE) and composite reliability. Convergent validity was confirmed when the outer loadings have loadings above 0.55 as proposed by Tabachnick \& Fidell, 2007 [99], as well as an average variance extracted of $>0.5$ and composite reliability of $>0.7$ as suggested by Hair Jr et al., 2016 [98] (see Table 3 and Figure 2).

Table 3. Measurement Model Results.

\begin{tabular}{|c|c|c|c|c|}
\hline Construct & Item & Loadings & CR & AVE \\
\hline \multirow[t]{5}{*}{ Attitude } & ATT1 & 0.789 & 0.85 & 0.536 \\
\hline & ATT2 & 0.575 & & \\
\hline & ATT3 & 0.797 & & \\
\hline & ATT4 & 0.81 & & \\
\hline & ATT5 & 0.662 & & \\
\hline \multirow[t]{4}{*}{ Subjective Norm } & SN1 & 0.68 & 0.893 & 0.679 \\
\hline & SN2 & 0.834 & & \\
\hline & SN3 & 0.855 & & \\
\hline & SN4 & 0.911 & & \\
\hline \multirow[t]{4}{*}{ Perceived Behavioral Control } & PBC1 & 0.704 & 0.822 & 0.536 \\
\hline & PBC2 & 0.751 & & \\
\hline & PBC3 & 0.682 & & \\
\hline & PBC4 & 0.788 & & \\
\hline \multirow[t]{4}{*}{ Purchase Intention } & PI1 & 0.772 & 0.817 & 0.528 \\
\hline & PI2 & 0.681 & & \\
\hline & PI3 & 0.762 & & \\
\hline & PI4 & 0.685 & & \\
\hline \multirow[t]{4}{*}{ Optimism } & OPPT1 & 0.568 & 0.836 & 0.565 \\
\hline & OPPT2 & 0.801 & & \\
\hline & ОРРТ3 & 0.842 & & \\
\hline & OPPT4 & 0.765 & & \\
\hline \multirow[t]{4}{*}{ Innovativeness } & INNO1 & 0.753 & 0.82 & 0.534 \\
\hline & INNO2 & 0.716 & & \\
\hline & INNO3 & 0.773 & & \\
\hline & INNO4 & 0.676 & & \\
\hline \multirow{4}{*}{ Discomfort } & DISC1 & 0.742 & 0.875 & 0.637 \\
\hline & DISC2 & 0.875 & & \\
\hline & DISC3 & 0.819 & & \\
\hline & DISC4 & 0.749 & & \\
\hline \multirow[t]{4}{*}{ Insecurity } & INSEC1 & 0.762 & 0.853 & 0.592 \\
\hline & INSEC2 & 0.795 & & \\
\hline & INSEC3 & 0.769 & & \\
\hline & INSEC4 & 0.749 & & \\
\hline
\end{tabular}


The discriminant validity was assessed using the Heterotrait-Monotrait (HTMT) ratio. The HeterotraitMonotrait (HTMT) ratio has recently been established as a superior criterion compared to the more traditional assessment methods, such as the Fornell-Larcker criterion [87]. The criterion of discriminant validity of Heterotrait-Monotrait Ratio of Correlations (HTMT) should be below 0.85 or $0.90[87,100]$. The results presented in the Table 4 illustrate that all the values ranging from 0.85 to 0.9 . Based on the results presented, it statistically fulfilled the Heterotrait-Monotrait(HTMT) ratio discriminant validity criteria suggested by Henseler et al., 2015 [87] that all the values are below than 0.90 .

Table 4. Discriminant Validity.

\begin{tabular}{ccccccccc}
\hline Heterotrait-Monotrait Ratio (HTMT) & & & & & & & & \\
\hline & ATT & DISC & INNO & INSEC & OPPT & PBC & PI & SN \\
ATT & & & & & & & & \\
DISC & 0.166 & & & & & & & \\
INNO & 0.685 & 0.063 & & & & & & \\
INSEC & 0.206 & 0.47 & 0.114 & & & & & \\
OPPT & 0.393 & 0.073 & 0.491 & 0.056 & & & & \\
PBC & 0.446 & 0.074 & 0.473 & 0.135 & 0.302 & & & \\
PI & 0.785 & 0.15 & 0.682 & 0.171 & 0.363 & 0.517 & & \\
SN & 0.068 & 0.279 & 0.132 & 0.358 & 0.071 & 0.082 & 0.081 \\
\hline
\end{tabular}

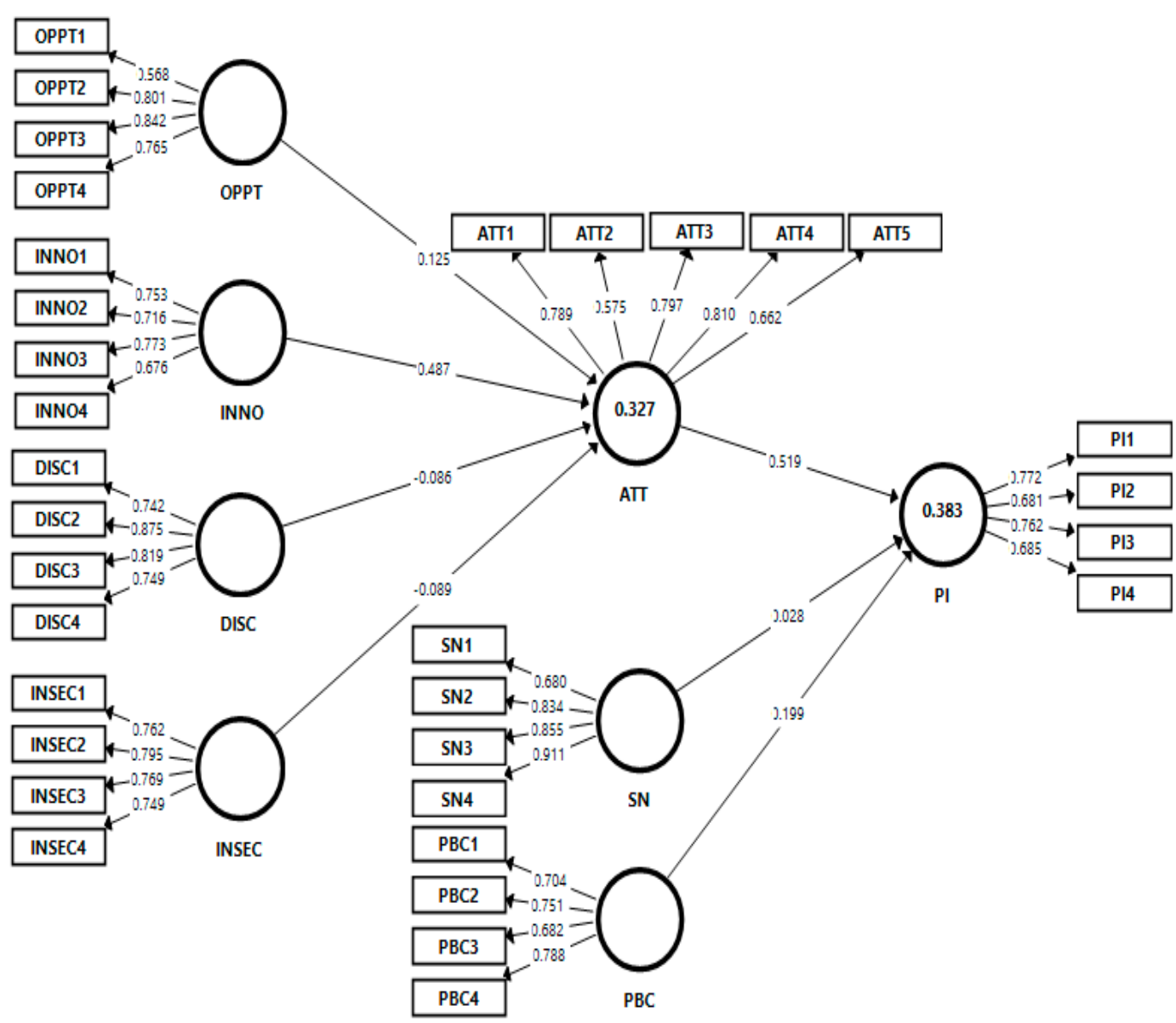

Figure 2. Direct Path coefficient of the structural model (PLS Algorithm).

\subsection{Structural Model Evaluation}

As discussed above, once the measurement model was confirmed as reliable and valid, the second step is to evaluate the structured model. Assessing the structural model involves the significance of the 
path coefficients, $\mathrm{R}^{2}$ values which represent the variance explained of each endogenous latent variable, $\left(f^{2}\right)$ effect size and finally the predictive relevance $\left(Q^{2}\right)$. The bootstrapping procedure (5000 resample) was performed to examine the significance of the path coefficients [100]. Hypothesized relationships $\mathrm{H} 1, \mathrm{H} 3, \mathrm{H} 4 \mathrm{a}, \mathrm{H} 4 \mathrm{~b}, \mathrm{H} 4 \mathrm{c}$ and $\mathrm{H} 4 \mathrm{~d}$ were proved to be significant while $\mathrm{H} 2$ was not supported. Table 5 shows the results of the hypothesis testing and structural relationships. Overall, the structural results imply that the proposed model explains $38.3 \%$ of variance to predict consumer intention to purchase energy-saving household products. The $R^{2}$ value of 0.383 was higher than the 0.35 (substantial) value suggested by Cohen (1988) [101], whereas the $Q^{2}$ values were all greater than 0 , which suggests that there is predictive relevance [100]. We also estimated $f^{2}$ as recommended by Hair Jr et al., 2016 [98]. Cohen (1988) [101] effect size values of $0.35,0.15$ and 0.02 representing large, medium and small effects respectively were used to assess the effect size as shown in Table 5.

Table 5. Structural model Results.

\begin{tabular}{cccccccccc}
\hline \multicolumn{7}{c}{ Results of SEM and Hypothesis Testing } \\
\hline Hypothesis & Relationship & $\begin{array}{c}\text { Path } \\
\text { Coefficient }\end{array}$ & $\begin{array}{c}\text { Std. } \\
\text { Error }\end{array}$ & $\boldsymbol{t}$ Value & $\boldsymbol{p}$ Value & Supported & $\mathbf{R}^{2}$ & $\mathbf{Q}^{2}$ & $f^{2}$ \\
\hline H1 & ATT->PI & 0.519 & 0.039 & 13.375 & 0 & Yes & 0.383 & 0.188 & 0.384 \\
H2 & SN->PI & 0.028 & 0.05 & 0.557 & 0.289 & No & 0.001 \\
H3 & PBC->PI & 0.199 & 0.048 & 4.162 & 0 & Yes & 0.056 \\
H4a & OPPT->ATT & 0.125 & 0.044 & 2.818 & 0.002 & Yes & 0.327 & 0.156 \\
H4b & INNO->ATT & 0.487 & 0.04 & 12.19 & 0 & Yes & 0.02 & 0.306 \\
H4c & INSEC->ATT & -0.089 & 0.041 & 2.141 & 0.016 & Yes & & 0.01 \\
H4d & DISC->ATT & -0.086 & 0.041 & 2.076 & 0.019 & Yes & & \\
\hline
\end{tabular}

\section{Discussion and Policy Implications}

The results of hypothesis testing revealed that six out of seven hypotheses were fully supported and one hypothesis was rejected. H1 proposed a positive association between residents' attitudes towards their buying intention of energy-saving products, and this was supported by the data $(\beta=0.519, p<0.05)$. It reveals that buyers with favorable positive attitude towards such products would substantially plan to purchase them. Previous studies support the consistency of this finding [14,53]. Ajzen, (1991) [38] asserted that consumers' favorable attitudes regarding a product are positively correlated to the intention of buying that product. Therefore the occurrence of this significant relationship is a strong predictor of their actual buying behavior. $73 \%$ of the total respondents $(n=396)$ have had the experience of buying such products. This is an indication of Pakistani household consumers' attitudes towards buying energy-saving products. In a consistent attempt to advance and support future purchases of energy-saving household products, policy makers should therefore provide certain incentives for manufacturers, importers and sellers of energy-saving products. Such incentives will facilitate end users, while reduced prices of energy-saving products will encourage residents to buy these products. Another way forward is imposing taxes on energy inefficient products which will lead towards higher prices for inefficient products. More expensive products will eventually affect household consumers' attitudes towards these products and discourage them from buying energy inefficient products. Recent research in Malaysia found that lower prices of household energy-saving products lead to more favorable attitudes towards buying such products [102].

One intriguing finding of this study is that subjective norms do not directly influence Pakistani household consumers' intentions of buying energy-saving products. H2 suggested a positive association between subjective norms and residents' buying intention of energy-saving products, but this was not supported by the data $(\beta=0.028, p<0.05)$. The finding of this non-significant association is contrary to a few previous studies $[14,54]$ which predicted that subjective norms play an important role in residents' intentions to buy energy-saving products. But these findings are not completely isolated as they are supported by past research $[7,103]$. Moreover, the results of this research align with the former research stream and reveal that subjective norms do not play a major role in determining consumer consumption behavior towards energy saving home appliances [83]. Insignificance of 
such a relationship infers that Pakistani household consumers would not be easily affected by the assessments of individuals near them about choices to buy energy-saving household products. Actually, an excessive number of remarks from others may even negatively influence purchasing intentions of household consumers. This contrasting finding could be a result of cultural differences between multiple countries. López-Mosquera et al., (2014) [103] asserted that subjective norms might influence the attitudes of consumers in an indirect way. In order to enhance the positive effect of subjective norms on resident's buying intentions of such products, policy makers should construct a social atmosphere of energy saving. Residents should be encouraged to influence others' intentions to buy energy-saving household products through a streamlined promotional campaign.

PBC has been highlighted as a key determinant of household consumers' energy saving behavior $[14,65]$. H3 predicted a positive relationship between perceived behavioral control and residents' buying intention of energy-saving products. The current study confirms this relationship ( $\beta=0.199, p<0.05)$ which is consistent with previous research findings $[7,14]$. The solid impact of perceived behavioral control signifies that when residents have better control over an energy-saving product and the capacity to buy it, they are most likely to buy it. Economic pressure can be considered as a vital perceived behavioral control for buying energy-saving products. Some European countries have formed policies to encourage reduced use of energy at homes by providing subsidies [104]; while in Pakistan there is a lack of such policies. Government could likewise actualize some motivation approaches to subsidize families who useless energy. For example, subsidies could be given to the individuals who utilize less power in the summer season. This in turn would form positive intentions for residents towards buying energy-saving home products.

To get an inclusive idea of technology oriented personality traits' impact on residents' attitude towards intentions of buying energy-saving home products, this study used TRI's four dimensions. $\mathrm{H} 4 \mathrm{a} \& 4 \mathrm{~b}$ predicted a positive relationship between attitude and two technology related personality dimensions known as 'Contributors towards attitude'. Results of this study confirm that optimism ( $\beta=0.125, p<0.05)$ and innovativeness $(\beta=0.487, p<0.05)$ have a positive relation with resident attitudes towards and intentions of buying energy-saving household products. These results are consistent with previous research [70,105]. Liljander et al., (2006) [70] proposed that Optimism and innovativeness dimensions of TRI have positive effects on attitudes towards using self-serving technologies, while Theotokis et al., (2008) [105] confirmed that optimism and innovativeness positively contribute towards use of technology based services. Optimism and innovativeness concern the possession of positive attitudes toward technology, such as people's beliefs of level of control, flexibility and efficiency [77]. Residents who perceive technology based energy saving products positively and think of them as a convenience in their life have favorable attitudes towards the purchasing of such products. Marketers and manufacturers of these products should focus on this aspect and highlight it in their promotional campaigns to form positive attitudes of household consumers. Awareness of new features, added benefits and long term energy saving costs of energy-saving home products can be very helpful in shaping positive attitudes towards purchasing these products. Customers can be attracted with free trials. Positive encounters with the technology will prompt better acceptance and a belief that supplanting energy inefficient products with technology based energy saving products will eventually benefit residents, ultimately engendering a positive attitude and a willingness to try energy-saving household products.

$\mathrm{H} 4 \mathrm{c} \& 4 \mathrm{~d}$ suggested a negative influence of technology on attitude towards buying energy-saving products and therefore known as 'Inhibitors towards attitude'. Results of insecurity $(\beta=-0.089$, $p<0.05)$ and discomfort $(\beta=-0.086, p<0.05)$ confirm these hypotheses. Such a result is consistent with previous literature [105]. Insecurity and discomfort prevents residents from forming a positive attitude towards technology based energy-saving household products and reduces their perceived ease of use and usefulness. Residents with a sense of technological insecurity and discomfort may worry about the negative consequences of technology use such as complexity or show a lack of trust towards these products. In order to reduce insecurity and discomfort towards new technology energy-saving 
products, decision makers should launch public awareness campaigns and focus on training people on how to use these home products. Product manuals with clear instructions about how to operate these products can be very handy, a digital interface showing energy consumption records with other suitable details and an effective warranty system can also mitigate household consumers' negative attitudes formed by insecurity and discomfort towards new technology. Further, manufacturers can design product interfaces that are simple and user friendly so that customers will accept them more readily.

To put it briefly, manufacturers must set their strategies in accordance with the level of customers' technology readiness, increase customer adoption of technology, and assist them in overcoming difficulties when using energy-saving home products. Promoting the consequences and benefits of energy savings can strongly form consumer intentions to buy energy-saving products. The absence of clear and detailed information about "green" energy saving products has been a challenge faced by consumers [106]. Marketers can utilize a comparative approach by highlighting the percentage of energy saved and yearly financial savings by using a specific energy-saving home appliance over an inefficient version of same type of product. The cost of green products has also been an obstacle towards their sales [107]. Various studies argue that apart from accessibility, higher cost is one of the key factors that discourage purchasers from settling on decisions that are moral or eco-friendly. It is thereby suggested that manufacturers of energy-saving household products should attempt to diminish obstructions to buyers by lowering their prices. The government should facilitate manufacturers by offering relevant incentives such as research and development encouragement incentives, tax rebates on technology transfers and related discounts that will eventually bring down the cost of energy-saving products. On the other hand, energy inefficient products should be discouraged by imposing additional taxes and duties on such products which will increase their prices.

Government agencies such as WAPDA, NEPRA, the Ministry of planning and the Ministry of energy should implement energy star labeling for all household energy products. Apart from mass media promotional campaigns, the organizations listed above could also hold road shows together with brands manufacturing such products in Pakistan. Consequently, with the assistance of this energy star labeling on home products, Pakistani residents will be better educated and this will improve the probability of their actual purchase. In the end marketers, manufacturers, policy makers, government agencies and other stakeholders should make a collaborative and holistic effort to promote energy-saving household products. Every available channel including electronic, print and social media, the education system and so on should be engaged in this pursuit. Educational institutions can play a vital role in cultivating awareness of the importance of energy efficiency. A special subject can be included in the curriculum of high schools by incorporating environmental sciences and energy related scientific knowledge. Students should be taught how our activities are associated with the nature and how individuals can contribute towards sustainable environment by using energy-saving products that can not only save energy but also have positive impact towards green environment.

\section{Limitations and Future Directions}

The current study offers several actionable implications along with a few notable limitations. The first limitation exists in terms of the generalisability of results. The concept of energy-saving home products in this study is macroscopic, but influencing factors may differ with the variation of product types e.g., air conditioners, washing machines, TVs, lighting products etc. Future research should focus on profiling consumer intentions towards specific categories of energy-saving home products. Secondly, we collected data mostly from young household consumers; future research can target other age segments, which may provide new insights. Thirdly, consumers' adoption behavior can be influenced by several motivators other than those described in this study, so other behavioral models can be used to broaden the understanding of these intentions. While the findings of the current study can be used as a baseline for enhancing our understanding of consumers' energy saving behavior, future studies can investigate whether this integrated research model stands up to 
scrutiny in other markets. Also, this model can be examined in the business organizations' purchasing context. This would be pertinent as businesses are typically responsible for high levels of energy usage compared to household consumers.

\section{Conclusions}

The current study focused on the determinants of household consumers' purchase intention towards buying energy saving products from the perspective of cognitive behavioral antecedents and technology related personality traits. For this purpose, we developed a theoretical model by combining the Theory of Planned Behavior (TPB) and Technology Readiness Index (TRI). In general this study examined the relationships between positive (optimism, innovativeness) and negative (discomfort, insecurity) technology related personality traits and household consumers' attitude towards purchase intentions of energy-saving products. Other hypotheses included positive association between attitude, subjective norm and PBC and purchase intentions respectively. Data was collected from household consumers of Pakistan by using a questionnaire. A structural equation modeling technique using PLS was used to test the research hypotheses. Six hypotheses were supported out of seven.

The results indicate that optimism and innovativeness have significant positive impacts on residents' attitude towards buying energy-saving products. At the same time discomfort and insecurity are negatively related with attitude towards these purchase intentions. Further, attitude and perceived behavioral control have positive significant relation with residents' purchase intentions while contrary to some prior studies, subjective norms do not have a significant association, which may be attributed to an overload of opinions from peers. Results of the study indicate that targeting technology embedded personality traits is very important in order to build positive consumer attitudes towards these tech based home products. TR effects on consumption behavior are well proven and stressed in extant literature $[43,48]$. But our study has revealed that focusing TR related personality traits in energy saving products' context is very crucial in the current context of technological advancements. Technology has revolutionized the flow of information. Access to mobile phones has spread to more than half the population on earth. With the help of mobile networks, information about energy saving products and their consequences can be conveyed to the broader public, which will enforce positive attitudes towards purchasing such appliances. Spreading the awareness of new features, their added benefits and long term energy saving costs should be the core focus of marketers and policy makers. Another technological implication is caused by the use of digital interfaces which continuously show the amount of energy consumed and saved by these appliances. People become more conscious about energy consumption and energy savings after being informed about such key metrics. Smart meters are also an example of this phenomenon. Additionally, government agencies should launch an energy saving drive and promote the use of energy-saving home products. This study has used cognitive behavioral aspects along with technology oriented personality traits. However future research can apply religion related behavioral aspects and general personality traits to find new insights in this domain of study.

Author Contributions: The authors contributed equally to this research. Conceptualization \& Writing of original manuscript: S.A. and H.U.; Reviewed and improved: M.A.; data collection \& analysis: W.A. and H.Z.

Funding: This research received no external funding.

Conflicts of Interest: The authors declare no conflict of interest.

\section{References}

1. Zhou, K.; Yang, S.; Shen, C.; Sun, S.D.C. Energy conservation and emission reduction of China's electric power industry. Renew. Sustain. Energy Rev. 2015, 45, 10-19. [CrossRef]

2. Jansson, J.; Nordlund, A.M.A. Green consumer behavior: Determinants of curtailment and eco-innovation adoption. J. Consum. Mark. 2010, 27, 358-370. [CrossRef] 
3. Environmental Protection Agency. Global Greenhouse Gas Emissions Data I Greenhouse Gas (GHG) Emissions; EPA: Washington, DC, USA, 2018.

4. Mosly, I.; Makki, A.A. Current status and willingness to adopt renewable energy technologies in Saudi Arabia. Sustainability 2018, 10, 4269. [CrossRef]

5. Rafique, M.M.; Rehman, S. National energy scenario of Pakistan-Current status, future alternatives, and institutional infrastructure: An overview. Renew. Sustain. Energy Rev. 2017, 69, 156-167. [CrossRef]

6. Meng, Y.; Yang, Y.; Chung, H.; Lee, P.H.; Shao, C. Enhancing Sustainability and Energy Efficiency in Smart Factories: A Review. Sustainability 2018, 10, 4779. [CrossRef]

7. Tan, C.S.; Ooi, H.Y.; Goh, Y.N. A moral extension of the theory of planned behavior to predict consumers' purchase intention for energy-efficient household appliances in Malaysia. Energy Policy 2017, 107, 459-471. [CrossRef]

8. United Nations. World Population Projected to Reach 9. United Nations. 2018. Available online: http: / /www.un.org/en/development/desa/news/population/2015-report.html (accessed 1 November 2018).

9. International Energy Agency. World Energy Outlook 2017; International Energy Agency: Paris, Frane, 2017; p. 13.

10. Ngo, A.; West, G.E.; Calkins, P.H. Determinants of environmentally responsible behaviours for greenhouse gas reduction. Int. J. Consum. Stud. 2009, 33, 151-161. [CrossRef]

11. Sorrell, S. Reducing energy demand: A review of issues, challenges and approaches. Renew. Sustain. Energy Rev. 2015, 47, 74-82. [CrossRef]

12. Zhou, K.; Yang, S. Understanding household energy consumption behavior: The contribution of energy big data analytics. Renew. Sustain. Energy Rev. 2016, 56, 810-819. [CrossRef]

13. Ek, K.; Patrik, P.S. The devil is in the details: Household electricity saving behavior and the role of information. Energy Policy 2010, 38, 1578-1587. [CrossRef]

14. Wang, Z.; Zhang, B.; Li, G. Determinants of energy-saving behavioral intention among residents in Beijing: Extending the theory of planned behavior. J. Renew. Sustain. Energy 2014, 6, 1-18. [CrossRef]

15. Mills, B.; Schleich, J. Analysis of Existing Data: Determinants for the Adoption of Energy-Efficient Household Appliances in Germany. In Sustainable Energy Consumption in Residential Buildings; Springer: Berlin, Germany, 2013; pp. 39-67.

16. Wang, Z.; Wang, X.; Guo, D. Policy implications of the purchasing intentions towards energy-efficient appliances among China's urban residents: Do subsidies work? Energy Policy 2016, 102, 430-439. [CrossRef]

17. European Commission. Action Plan for Energy Efficiency: Realising the Potential; European Commission: Brussels, Belgium, 2006.

18. Nejat, P.; Jomehzadeh, F.; Taheri, M.M.; Gohari, M.; Majid, M.Z.A. A global review of energy consumption, $\mathrm{CO}_{2}$ emissions and policy in the residential sector (with an overview of the top ten $\mathrm{CO}_{2}$ emitting countries). Renew. Sustain. Energy Rev. 2015, 43, 843-862. [CrossRef]

19. International Energy Agency. Efficiency; International Energy Agency: Paris, France, 2011.

20. Kanemoto, K.; Moran, D.; Lenzen, M.; Geschke, A. International trade undermines national emission reduction targets: New evidence from air pollution. Glob. Environ. Chang. 2014, 24, 52-59. [CrossRef]

21. Lau, L.-S.; Choong, C.-K.; Eng, Y.-K. Investigation of the environmental Kuznets curve for carbon emissions in Malaysia: Do foreign direct investment and trade matter? Energy Policy 2014, 68, 490-497. [CrossRef]

22. Pablo-Romero, M.; Pozo-Barajas, R.; Yñiguez, R. Global changes in residential energy consumption. Energy Policy 2017, 101, 342-352. [CrossRef]

23. Parikh, K.S.; Parikh, J.K. Realizing potential savings of energy and emissions from ef fi cient household appliances in India. Energy Policy 2016, 97, 102-111. [CrossRef]

24. Andrews-speed, P.; Ma, G.; Andrews-Speed, P.; Zhang, J. Chinese consumer attitudes towards energy saving: The case of household electrical appliances in Chongqing. Energy Policy 2013, 56, 591-602.

25. McNeil, M.A.; Letschert, V.E. Future Air Conditioning Energy Consumption in Developing Countries and What Can Be Done about It: The Potential of Efficiency in the Residential Sector; Lawrence Berkeley National Laboratory: Berkeley, CA, USA, 2008.

26. Worldometer. Pakistan Population-Worldometers. 2018. Available online: http://www.worldometers. info/world-population/indonesia-population/ (accessed on 5 November 2018).

27. Kugelman, M. Pakistan's energy crisis. PetroMin 2013, 26, 16-22. 
28. Valasai, G.D.; Uqaili, M.A.; Memon, H.U.R.; Samoo, S.R.; Harijan, N.H.M.K. Overcoming electricity crisis in Pakistan: A review of sustainable electricity options. Renew. Sustain. Energy Rev. 2017, 72, 734-745. [CrossRef]

29. Khan, H.A.; Pervaiz, S. Technological review on solar PV in Pakistan: Scope, practices and recommendations for optimized system design. Renew. Sustain. Energy Rev. 2013, 23, 147-154. [CrossRef]

30. Ministry of Water and Power. Press Release. 2018. Available online: http://mowp.gov.pk/frmDetails.aspx. (accessed on 5 December 2018).

31. State Bank of Pakistan. The State Of Pakistan's Economy; State Bank of Pakistan: Karachi, Pakistan, 2018.

32. Ministry of Planning Development \& Reform. Pakistan Vision 2025. 2017. Available online: https: / / www. pc.gov.pk/ (accessed on 5 November 2018).

33. Pothitou, M.; Hanna, R.F.; Chalvatzis, K.J. Environmental knowledge, pro-environmental behaviour and energy savings in households: An empirical study. Appl. Energy 2016, 184, 1217-1229. [CrossRef]

34. Gadenne, D.; Sharma, B.; Kerr, D.; Smith, T. The influence of consumers' environmental beliefs and attitudes on energy saving behaviours. Energy Policy 2011, 39, 7684-7694. [CrossRef]

35. Abrahamse, W.; Steg, L. How do socio-demographic and psychological factors relate to households' direct and indirect energy use and savings? J. Econ. Psychol. 2009, 30, 711-720. [CrossRef]

36. Tanner, C.; Kast, S.W. Promoting sustainable consumption: Determinants of green purchases by Swiss consumers. Psychol. Mark. 2003, 20, 883-902. [CrossRef]

37. Niemeyer, S. Consumer voices: Adoption of residential energy-efficient practices. Int. J. Consum. Stud. 2010, 34, 140-145. [CrossRef]

38. Ajzen, I. The theory of planned behavior. Organ. Behav. Hum. Decis. Process. 1991, 50, 179-211. [CrossRef]

39. Chan, K. Mass communication and pro-environmental behaviour: Waste recycling in Hong Kong. J. Environ. Manag. 1998, 52, 317-325. [CrossRef]

40. Reyes-Menendez, A.; Saura, J.R.; Palos-Sanchez, P.R.; Alvarez-Garcia, J. Understanding User Behavioral Intention to Adopt a Search Engine that Promotes Sustainable Water Management. Symmetry 2018, 10, 584. [CrossRef]

41. Millock, K.; Nauges, C. Household adoption of water-efficient equipment: The role of socio-economic factors, environmental attitudes and policy. Environ. Resour. Econ. 2010, 46, 539-565. [CrossRef]

42. Rhodes, R.E.; Jones, L.E.E. Personality, the Theory of Planned Behavior, and Exercise. J. Appl. Soc. Psychol. 2002, 32, 1721-1736. [CrossRef]

43. Walczuch, R.; Streukens, J.L.S. The Effect of Service Employees' Technology Readiness on Technology Acceptance. Inform. Manag. 2007, 44, 206-215. [CrossRef]

44. Kumar, V.; Kumar, S.; Chandra, B. Big Five Personality Traits and Tourist's Intention to Visit Green Hotels. Indian J.Sci.Res. 2017, 15, 79-87.

45. Dezdar, S. Article information: Green Information Technology Adoption: Influencing Factors and Extension of Theory of Planned Behavior. Soc. Responsib. J. 2017, 13, 292-306. [CrossRef]

46. Parasuraman, A.; Colby, C.L. An Updated and Streamlined Technology Readiness Index: TRI 2.0. J. Serv. Res. 2015, 18, 59-74. [CrossRef]

47. Rogers, E.M.; Svenning, L. Difussion of Innovation; The Free Press: New York, NY, USA, 1995.

48. Al-Ajam, A.S.; Md Nor, K. Challenges of adoption of internet banking service in Yemen. Int. J. Bank Mark. 2015, 33, 178-194. [CrossRef]

49. Parasuraman, A. Index (TRI) A Multiple-Item Scale to Embrace New Technologies. J. Service Res. 2000, 2, 307-320. [CrossRef]

50. Ivancevich, J.M.; Matteson, M.T. Stress and Work: A Managerial Perspective; Scott Foresman: Glenview, IL, USA; Sage Publishing: Thousand Okas, CA, USA, 1980.

51. Zografakis, N.; Sifaki, E.; Pagalou, M.; Nikitaki, G.; Psarakis, V.; Tsagarakis, K.P. Assessment of public acceptance and willingness to pay for renewable energy sources in Crete. Renew. Sustain. Energy Rev. 2010, 14, 1088-1095. [CrossRef]

52. Greaves, M.; Zibarras, L.D.; Stride, C. Using the theory of planned behavior to explore environmental behavioral intentions in the workplace. J. Environ. Psychol. 2013, 34, 109-120. [CrossRef]

53. Ha, H.Y.; Janda, S. Predicting consumer intentions to purchase energy-efficient products. J. Consum. Mark. 2012, 29, 461-469. [CrossRef] 
54. Finlay, K.A.; Trafimow, D.; Moroi, E. The importance of subjective norms on intentions to perform health behaviors. J. Appl. Soc. Psychol. 1999, 29, 2381-2393. [CrossRef]

55. Thøgersen, J.; Grønhøj, A. Electricity saving in households-A social cognitive approach. Energy Policy 2010, 38, 7732-7743. [CrossRef]

56. Ajzen, I.; Fishbein, M. Attitudes and normative beliefs as factors influencing behavioral intentions. J. Pers. Soc. Psychol. 1972, 21, 1-9. [CrossRef]

57. Ozaki, R.; Sevastyanova, K. Going hybrid: An analysis of consumer purchase motivations. Energy Policy 2011, 39, 2217-2227. [CrossRef]

58. Albayrak, T.; Aksoy, Ş.; Caber, M. The effect of environmental concern and scepticism on green purchase behaviour. Mark. Intell. Plan. 2013, 31, 27-39. [CrossRef]

59. Chen, M.-F.; Tung, P.-J. Developing an extended theory of planned behavior model to predict consumers' intention to visit green hotels. Int. J. Hosp. Manag. 2014, 36, 221-230. [CrossRef]

60. Kim, E.; Ham, S.; Yang, I.S.; Choi, J.G. The roles of attitude, subjective norm, and perceived behavioral control in the formation of consumers' behavioral intentions to read menu labels in the restaurant industry. Int. J. Hosp. Manag. 2013, 35, 203-213. [CrossRef]

61. Webb, D.; Soutar, G.N.; Mazzarol, T.; Saldaris, P. Self-determination theory and consumer behavioural change: Evidence from a household energy-saving behaviour study. J. Environ. Psychol. 2013, 35, 59-66. [CrossRef]

62. Klöckner, C.A. A comprehensive model of the psychology of environmental behaviour-A meta-analysis. Glob. Environ. Chang. 2013, 23, 1028-1038. [CrossRef]

63. Alam, S.S.; Hashim, N.H.N.; Rashid, M.; Omar, N.A.; Ahsan, N.; Ismail, M.D. Small-scale households renewable energy usage intention: Theoretical development and empirical settings. Renew. Energy 2014, 68, 255-263. [CrossRef]

64. Oikonomou, V.; Becchis, F.; Russolillo, L.S.D. Energy saving and energy efficiency concepts for policy making. Energy Policy 2009, 37, 4787-4796. [CrossRef]

65. Darby, S. Energy advice-What is it worth. Proc. Eur. Counc. 1999, 5, 3-5.

66. Orbis Reseach. Global Smart Home Appliances Market Analysis 2012-2017 and Forecast 2018-2023; Orbis Reseach: Dallas, TX, USA, 2018.

67. Philips. Annual Report 2014; Philips: Amsterdam, The Netherlands, $2014 . \quad$ Available online: https:/ / www.philips.com/c-dam/corporate/about-philips/investors/financial-results/annualreports/PhilipsFullAnnualReport2014_English.pdf (accessed on 4 Spetember 2018).

68. Economist Intelligence Unit. Digital Economy Rankings 2010 Beyond E-readiness. The Economist, 2010. Available online: https:/ /www.ibm.com/services/us/gbs/bus/html/ibv-digitaleconomy2010.html (accessed on 5 March 2019).

69. International Telecommunication Union. Measuring the Information Society Report 2014; International Telecommunication Union: Geneva, Switzerland, 2014.

70. Liljander, V.; Gillberg, F.; van Riel, J.G.A. Technology readiness and the evaluation and adoption of self-service technologies. J. Retail. Consum. Serv. 2006, 13, 177-191. [CrossRef]

71. Lester, P. Future Home Tech: 8 Energy-Saving Solutions on the Horizon; United States Department of Energy: Washington, DC, USA, 2015.

72. Navigant Research. Energy Efficient Buildings Global Outlook; Navigant Research: Boulder, CO, USA, 2017.

73. Meuter, M.L.; Ostrom, A.L.; Bitner, M.J.; Roundtree, R. The influence of technology anxiety on consumer use and experiences with self-service technologies. J. Bus. Res. 2003, 56, 899-906. [CrossRef]

74. Tsikriktsis, N. A Technology Readiness-Based Taxonomy of Customers: A Replication and Extension. J. Serv. Res. 2004, 7, 42-52. [CrossRef]

75. Bruner, G.C.; Kumar, A. Gadget lovers. J. Acad. Mark. Sci. 2007, 35, 329-339. [CrossRef]

76. Rojas-Méndez, J.I.; Parasuraman, A.; Papadopoulos, N. Demographics, attitudes, and technology readiness. Mark. Intell. Plan. 2017, 35, 18-39. [CrossRef]

77. Kuo, K.; Liu, C.; Ma, C. An Investigation of the Effect of Nurses' Technology Readiness on the Acceptance of Mobile Electronic Medical Record Systems. J. Res. Nurs. 2013. [CrossRef]

78. Abidur, S.; Khadijeh, S.; Ramayah, T.; Mohammad, M.; Alam, D. Technological Forecasting \& Social Change Technology acceptance among micro-entrepreneurs in a marginalized social strata: The case of social innovation in Bangladesh. Technol. Forecast. Soc. Chang. 2017, 118, 236-245. 
79. Agarwal, R.; Prasad, J. Are individual differences germane to the acceptance of new information technologies? Decis. Sci. 1999, 30, 361-391. [CrossRef]

80. Chen, M.F.; Lin, N.P. Incorporation of health consciousness into the technology readiness and acceptance model to predict app download and usage intentions. Internet Res. 2018, 28, 351-373. [CrossRef]

81. Rosen, L.D.; Weil, M.M. Adult and teenage use of consumer, business, and entertainment technology: Potholes on the information superhighway? J. Consum. Aff. 1995, 29, 55-84. [CrossRef]

82. Valente, T.W.; Davis, R.L. Accelerating the diffusion of innovations using opinion leaders. Ann. Am. Acad. Pol. Soc. Sci. 1999, 566, 55-67. [CrossRef]

83. Ninh, T.; Lobo, A. Journal of Retailing and Consumer Services Pro-environmental purchase behaviour: The role of consumers' biospheric values. J. Retail. Consum. Serv. 2016, 33, 98-108.

84. Churchill, G.A.; Iacobucci, D. Marketing Research: Methodological Foundations; Dryden Press: New York, NY, USA, 2006.

85. Kanchanapibul, M.; Lacka, E.; Wang, X.; Chan, H.K. An empirical investigation of green purchase behaviour among the young generation. J. Clean. Prod. 2014, 66, 528-536. [CrossRef]

86. Cenfetelli, R.T.; Bassellier, G. Interpretation of formative measurement in information systems research. MIS Q. 2009, 33, 689-707. [CrossRef]

87. Henseler, J.; Ringle, C.M.; Sarstedt, M. A new criterion for assessing discriminant validity in variance-based structural equation modeling. J. Acad. Mark. Sci. 2015, 43, 115-135. [CrossRef]

88. Richter, N.F.; Cepeda, G.; Roldán, J.L.; Ringle, C.M. European management research using partial least squares structural equation modeling (PLS-SEM). Eur. Manag. J. 2016, 34, 589-597. [CrossRef]

89. Chin, W.W.; Newsted, P.R. Structural equation modeling analysis with small samples using partial least squares. Stat. Strateg. Small Sample Res. 1999, 1, 307-341.

90. Ramayah, T.; Ahmad, N.H.; Halim, H.A.; Zainal, S.R.M.; Lo, M.-C. Discriminant analysis: An illustrated example. Afr. J. Bus. Manag. 2010, 4, 1654-1667.

91. Osborne, J.W. Improving your data transformations: Applying the Box-Cox transformation. Pract. Assess. Res. Eval. 2010, 15, 1-9.

92. Ringle, C.M.; Wende, S.; Becker, J.-M. SmartPLS 3; SmartPLS GmbH: Boenningstedt, Germany, 2015.

93. Hair, J.F.; Ringle, C.M.; Sarstedt, M. PLS-SEM: Indeed a silver bullet. J. Mark. Theory Pract. 2011, 19, 139-152. [CrossRef]

94. Henseler, J.; Ringle, C.M.; Sinkovics, R.R. The use of partial least squares path modeling in international marketing. In New Challenges to International Marketing; Emerald Group Publishing Limited: Bingley, UK, 2009; pp. 277-319.

95. Ringle, C.M.; Boysen, N.; Wende, S.; Will, A. Messung von Kausalmodellen mit dem Partial-LeastSquares-Verfahren. Wirtschaftsstudium 2006, 35, 81-88.

96. Wilson, B. Using PLS to investigate interaction effects between higher order branding constructs. In Handbook of Partial Least Squares; Springer: Berlin, Germany, 2010; pp. 621-652.

97. Anderson, J.C.; Gerbing, D.W. Structural equation modeling in practice: A review and recommended two-step approach. Psychol. Bull. 1988, 103, 411-423. [CrossRef]

98. Hair, J.F.; Hult, G.T.M.; Ringle, C.; Sarstedt, M. A primer on Partial Least Squares Structural Equation Modeling (PLS-SEM); Sage Publications: Thousand Oaks, CA, USA, 2016.

99. Tabachnick, B.G.; Fidell, L.S. Multivariate analysis of variance and covariance. Using Multivar. Stat. 2007, 3, 402-407.

100. Rasoolimanesh, S.M.; Roldán, J.L.; Jaafar, M.; Ramayah, T. Factors influencing residents' perceptions toward tourism development: Differences across rural and urban world heritage sites. J. Travel Res. 2017, 56, 760-775. [CrossRef]

101. Cohen, J. Statistical Power Analysis for the Behavioral Sciences, 2nd ed.; Erlbaum Associates: Hillsdale, MI, USA, 1988.

102. Ariff, M. Need to Increase Usage of Energy Efficient Products. Bernama News. Available online: http: / / kpdnkk.bernama.com/featuresEn.php?Id=1024991 (accessed on 10 February 2017).

103. López-Mosquera, N.; García, T.; Barrena, R. An extension of the Theory of Planned Behavior to predict willingness to pay for the conservation of an urban park. J. Environ. Manag. 2014, 135, 91-99. [CrossRef]

104. McGilligan, C.; Sunikka-Blank, M.; Natarajan, S. Subsidy as an agent to enhance the effectiveness of the energy performance certificate. Energy Policy 2010, 38, 1272-1287. [CrossRef] 
105. Theotokis, A.; Vlachos, P.A.; Pramatari, K. The Moderating Role of Customer-Technology Contact on Attitude towards Technology-Based Services; Palgrave Macmillan: Basingstoke, UK, 2008; pp. 343-351.

106. Pickett-Baker, J.; Ozaki, R. Pro-environmental products: Marketing influence on consumer purchase decision. J. Consum. Mark. 2008, 25, 281-293. [CrossRef]

107. Wagner, S.A. Understanding Green Consumer Behaviour: A Qualitative Cognitive Approach; Routledge: Abingdon, UK, 2002. 